\title{
Pengaruh Pertumbuhan Perusahaan, Profitabilitas, Solvabilitas dan Opini Audit Going Concern Tahun Sebelumnya Terhadap Opini Audit Going Concern
}

\author{
Julfan Saputra \\ Program Pasca Sarjana \\ Universitas Muhammadiyah Sumatera Utara \\ julfansaputra91@gmail.com
}

Eka Nurmala Sari*

Universitas Muhammadiyah Sumatera Utara

*Coresponding Autor: ekanurmala@umsu.ac.id

\author{
Widia Astuty \\ Universitas Muhammadiyah Sumatera Utara \\ widiaastuty@umsu.ac.id
}

https://doi.org/10.30596/jrab.v21i1.6232

\begin{abstract}
This study aims to determine how much influence the company's growth, profitability, solvency and previous year's going concern audit opinion has on going concern audit opinion on mining companies listed on the Indonesia Stock Exchange. The population used in this study are all mining companies listed on the Indonesia Stock Exchange in 2014-2018. The analysis technique in this study used descriptive statistics with the help of the SPSS program. The regression used in this study is logistic regression. The results showed that the influence of company growth, profitability, solvency, and previous year's going concern audit opinion on going concern audit opinion on mining companies listed on the Indonesia Stock Exchange, based on the following indicators: First, company growth has no effect on going audit opinion. concern which means. When the company's growth increases, there are other burdens that must be covered so that the company's profits do not follow the company's growth. Second, profitability has an effect on going concern audit opinion, which means that if the company's profitability increases, the chances of the company receiving going concern audit opinion will decrease. Third, solvency has no effect on going concern audit opinion, this is because in providing a going concern audit opinion the auditor does not only focus on solvency ratio considerations but there are other factors that are taken into consideration for the auditor to provide a going concern audit opinion. Fourth, the previous year's going concern audit opinion affects the going concern audit opinion, meaning that when the company receives the previous year's going concern audit opinion, the company will receive the going concern audit opinion in the current year. Fifth, there is a joint (simultaneous) influence on company growth, profitability, solvency and previous year's going concern audit opinion on going concern audit opinion
\end{abstract}

Keyword : Company Growth, Profitability, Solvency, Previous year's Going Concern Audit Opinion, Going Concern Audit Opinion

Cara Sitasi : Saputra,J., Sari,N,S., Astuty,.W.(2020). Pengaruh Pertumbuhan Perusahaan, Profitabilitas, Solvabilitas dan Opini Audit Going Concern Tahun Sebelumnya Terhadap Opini Audit Going concern.Jurnal Riset Akuntansi dan Bisnis, vol 21.(1) hal 15-25 https://doi.org/10.30596/jrab.v21i1.6232 


\section{Jurnal Riset Akuntansi dan Bisnis}

Vol 21 No 1 2021, hal 15-25

ISSN 1693-7597 (Print), 2623-2650 (online)

Available online: http://jurnal.umsu.ac.id/index.php/akuntan

\section{PENDAHULUAN}

Opini audit going concern merupakan asumsi dalam pelaporan keuangan suatu entitas sehingga jika suatu entitas mengalami kondisi yang berlawanan dengan asumsi kelangsungan usaha, maka entitas tersebut dimungkinkan mengalami masalah untuk survive. Sekalipun tujuan audit bukan untuk mengevaluasi kesehatan keuangan perusahaan, auditor memiliki tanggung jawab menurut SAS (AU 341) untuk mengevaluasi apakah perusahaan mempunyai kemungkinan untuk bertahan (Arens, 2008). Seorang auditor akan memberikan opini audit going concern pada perusahaan ketika auditor merasa terjadi keraguan terhadap kemampuan perusahaan tersebut dalam mempertahankan kelangsungan usahanya, apabila auditor beranggapan bahwa perusahaan tersebut tidak mampu bertahan lama maka akan diberikan opini audit going concern. (Haris, 2015)Kelangsungan hidup (going concern) perusahaan menjadi hal yang sangat dibutuhkan bagi pihak yang berkepentingan terutama para investor. Keberadaan entitas bisnis dalam jangka panjang memiliki tujuan untuk mampu mempertahankan kelangsungan hidup (going concern) perusahaan. Kondisi yang dialami oleh suatu perusahaan dapat memberikan sinyal kelangsungan usaha perusahaan, seperti kerugian operasi yang signifikan dan berlangsung secara terus menerus sehingga menyebabkan keraguan pada kelangsungan hidup perusahaan (Krissindiastuti, M, 2016).

Fenomena yang terjadi pada tahun 2015 perusahaan pertambangan global terbesar mencatat kerugian bersih kolektif (US\$27 miliar). Peristiwa Ini merupakan yang pertama dalam sejarah dimana kapitalisasi pasar turun sebesar 37\%. Dan lebih dari itu penurunan ini bahkan secara efektif menghapus keuntungan yang diperoleh selama siklus super komoditas. Tahun 2015 menjadi tahun tantangan terberat bagi sektor pertambangan. Penurunan harga komoditas sebesar 25\% dibandingkan tahun sebelumnya. Dengan melakukan peningkatan produktivitas, seperti berjuang untuk bertahan, disertai dengan pelepasan aset atau penutupan aset agar perusahaan masih bisa bertahan (www.PwC.com, 2016). Perusahaan tambang Indonesia dalam masa-masa ini harus berjuang mengatasi masalah lemahnya harga komoditi juga menurunnya permintaan dari Tiongkok dan negara berkembang lainnya. Hal ini menyebabkan penurunan yang signifikan atas kinerja keuangan perusahaan pertambangan di Indonesia. Indonesia menjelaskan kapitalisasi pasar keseluruhan perusahaan pertambangan yang tercatat di Bursa Efek Indonesia turun dari Rp 255 triliun pada tanggal 31 Desember 2014 menjadi Rp 161 triliun pada tanggal 31 Desember 2015 (www.PwC.com, 2016). Adanya kejadian di atas dipicu dari kondisi perekonomian global yang kurang kondusif berdampak pada penurunan harga global batubara. Sebagai akibatnya, perusahaan akan membukukan rugi bersih sebesar US\$ 24.618 untuk tahun yang berakhir pada tanggal 31 Desember 2014. Rencana manajemen untuk mengatasi kondisi tersebut juga biasanya telah diungkapkan pada catatan atas laporan keuangan konsolidasian, dari beberapa keterangan di atas maka perusahaan akan dapat mempertahankan kelangsungan usahanya (Annual Report ARII, 2014). Penurunan harga komoditas didorong dengan melemahnya saham-saham sejak awal Januari 2015 hingga Desember 2015. Perusahaan pertambangan seperti PT Aneka Tambang Tbk (ANTM), PT Bukit Asam Tbk (PTBA), PT Indo Tambangraya Megah Tbk (ITMG). Penurunan harga komoditas dapat mengakibatkan kerugian bagi perusahaan yang pada akhirnya akan berdampak pada keraguan kelangsungan suatu perusahaan yang diungkapkan oleh auditor dalam opini audit (www.tribunnews.com).

Faktor opini audit going concern berdasarkan pertumbuhn perusahaan pada PT Adaro Energy Tbk (ADRO) sebagai salah satu perusahaan tambang batu bara terbesar di Indonesia mengalami penurunan volume penjualan batu bara lebih karena kondisi pasar yang sampai sekarang masih kelebihan pasokan. Permintaan dari negara-negara konsumen batu bara dunia seperti Cina dan India juga turun. Sepanjang tahun 2015 Adaro memproduksi 51,46 juta MT batu bara. Angka ini lebih rendah 8\% dibanding 2014. Bahkan dari target yang ditetapkan antara 52-54 juta MT, perseroan memproduksi dibawah target. Hal ini 


\section{Jurnal Riset Akuntansi dan Bisnis \\ Vol 21 No 1 2021, hal 15-25 \\ ISSN 1693-7597 (Print), 2623-2650 (online) \\ Available online: http://jurnal.umsu.ac.id/index.php/akuntan}

dimakluki karena tren harga yang masih cenderung melemah dan juga permintaan yang cenderung turun. Merosotnya penjualan tersebut berdampak langsung terhadap laba bersih perusahaan dan mengakibatkan perusahaan akan mengalami going concern. Berdasarkan Profitabilitas, PT Toba Bara Sejahtera Tbk (TOBA) mencatatkan laba bersih sebesar US\$ 9,53 juta di sembilan bulan pertama 2015, Jika dibandingkan dengan periode yang sama tahun lalu pada angka US\$ 17,04 juta, itu artinya laba bersih perusahaan tersebut tercatat anjlok 44,07 persen. Anjloknya laba bersih perusahaan sampai dengan kuartal III 2015 tak lepas dari melemahnya harga batubara yang saat ini berada di bawah level US\$ 60\% per ton. Menurunnya laba perusahaan tiap tahun akan mengakibatkan perusahaan mengalami going concern.

Berdasarkan Solvabilitas, Petroselat Ltd mengalami pailit, Kepailitan anak usaha PT Sugih Energy Tbk ini terbilang dramatis. Telah terjadi berbagai perselisihan sejak putusan pailit 5 Juli 2017 lalu hingga putusan insolvensi pada 30 November 2017. Wilayah Kerja Petroselat di Selat Panjang Riau rencananya akan diterminasi pemerintah pada 4 Desember 2017, tapi akhirnya diundur hingga Januari 2018. Berdasarkan catatan kurator, Petroselat memiliki utang kepada 47 kreditur dengan total Rp117,65 miliar. Ketidakmampuan perusahaan dalam membayar hutang dan memiliki hutang yang cukup besar dapat menyebabkan opini audit going concern. Dan berdasarkan opini audit going concern tahun sebelumnya Bara Jaya Internasional TBK mendapatkan opini audit going concern di tahun 2018, namun di tahun 2019 dikeluarkan dari Bursa Efek Indonesia karena tidak memiliki keberlangsungan usaha.Dari fenomena-fenomena diatas, pengeluaran opini audit going concern oleh auditor terhadap perusahaan menunjukkan bahwa pertumbuhan perusahaan mengalami perlambatan, profitabilitas mengalami penurunan, solvabilitas yang tinggi dan mendapatkan opini audit going concern tahun sebelumnya. Berdasarkan www.sahamok.com diketahui bahwa perusahaan pertambangan yang tidak bisa mempertahankan kelangsungan usahanya antara lain ATPK (PT. Bara Jaya Tbk); JPRS (PT. Jaya Pari Steel Tbk.); SQBB (PT. Taisho Pari Steel Tbk); BRAU (Berau Coal Energy Tbk.); TKGA (Permata Prima Sakti Tbk.); dan DAVO (PT. Davomas Abadi Tbk).

Dari uraian tersebut dapat disimpulkan beberapa faktor yang mempengaruhi opini audit going concern diantaranya pertumbuhan perusahan, profitabilitas, solvabilitas dan opini audit going concern tahun sebelumnya. Pertumbuhan perusahaan dapat dijadikan indikator untuk menilai apakah suatu badan usaha masih bisa bertahan atau tidak untuk periode berikutnya. Rasio pertumbuhan penjualan digunakan sebagai indokator karena dapat menggambarkan keadaan perusahaan yang sedang baik. Profitabilitas termasuk factor yang mempengaruhi opini audit going concern merupakan suatu ukuran untuk mengetahui kemampuan perusahaan dalam menghasilkan laba yang berkaitan dengan penjualan, aset, dan saham sendiri. Solvabilitas termasuk faktor yang mempengaruhi opini audit going concern merupakan kemampuan suatu perusahaan untuk membayar semua hutanghutangnya baik jangka pendek maupun jangka Panjang (Rahmadani, 2016). Dan Opini audit going concern tahun sebelumnya adalah opini audit yang diperoleh suatu perusahaan pada satu tahun sebelum penelitian.

\section{KAJIAN TEORI}

\section{Opini Audit Going Concern}

Arens (2008) mengemukakan bahwa laporan audit adalah langkah terakhir dari seluruh proses audit. Auditor menggunakan laporan audit sebagai media untuk berhubungan dengan lingkungannya. Standar audit membagi opini audit menjadi 2 macam, yaitu:

1. Opini tanpa modifikasian (SA 700)

Opini wajar tanpa pengecualian Opini ini dikeluarkan jika berdasarkan hasil audit laporan keuangan telah disajikan secara wajar dalam semua hal yang material telah sesuai dengan prinsip akuntansi yang berlaku umum.

2. Opini dengan modifikasi (SA 705) 


\section{Jurnal Riset Akuntansi dan Bisnis}

Vol 21 No 1 2021, hal 15-25

ISSN 1693-7597 (Print), 2623-2650 (online)

Available online: http://jurnal.umsu.ac.id/index.php/akuntan

a. Pendapat wajar dengan pengecualian dapat diberikan ketika auditor meyakini atas dasar auditnya bahwa laporan keuangan ditemukan kesalahan dalam laporan keuangan yang mempunyai nilai material tetapi tidak pervasif.

b. Pendapat tidak wajar dimana menurut pandangan auditor, laporan keuangan yang dilaporkan secara tidak adil atau wajar dan terdapat kesalahan yang material serta pervasif.

c. Pernyataan tidak memberikan pendapat Auditor tidak mendapatkan perolehan bukti yang cukup sebagai bahan pertimbangan dalam menyampaikan opini audit.

\section{Going Concern}

Going concern adalah kemampuan perusahaan dalam mempertahankan kelangsungan hidupnya dalam jangka waktu yang pantas, yaitu tidak lebih dari satu tahun sejak tanggal laporan keuangan auditan. Masalah going concern terbagi dua, yaitu masalah keuangan yang meliputi kekurangan likuidasi, defisiensi ekuitas, penunggakan utang, kesulitan mendapatkan dana, serta masalah operasi yang meliputi kerugian operasi yang terus menerus, prospek pendapatan yang meragukan, kemampuan operasi terancam dan pengendalian yang lemah atas operasi (Hidayat, 2018) Asumsi going concern dijadikan salah satu asumsi yang dapat digunakan dalam penyusunan laporan keuangan perusahaan. Kelangsungan hidup perusahaan menjadi asumsi pelaporan keuangan selama tidak terdapat hal yang menunjukan informasi yang tidak sesuai. Ketidaksesuaian yang terjadi atas informasi suatu entitas apabila perusahaan tersebut tidak dapat melunasi utang jatuh tempo. Pemberhentian penjualan sebagian besar aktiva kepada pihak eksternal melalui bisnis SA Seksi 341 (Izzati, 2014)

\section{Penerimaan Opini Audit Going concern}

Going concern menurut Belkaoi (2000) dalam Alexander (2004) adalah suatu dalil yang menyatakan bahwa kesatuan usaha akan menjalankan terus operasinya dalam jangka waktu yang cukup lama untuk mewujudkan proyeknya, tanggung jawab serta aktivitas-aktivitasnya yang tidak berhenti. Dalil ini memberi gambaran bahwa suatu entitas akan diharapkan untuk beroperasi dalam jangka waktu yang tidak terbatas atau tidak diarahkan menuju ke arah likuidasi. Opini audit going concern merupakan opini yang dikeluarkan oleh auditor untuk memastikan apakah perusahaan dapat mempertahankan kelangsungan hidupnya. Satu bentuk khusus ketidakpastian yang harus dipertimbangkan auditor adalah kelanjutan entitas bisnis. Suatu bisnis dalam kondisi dapat melanjutkan usahanya jika dapat beroperasi di masa mendatang dan memenuhi kewajibannya. (Nurdiono et al., 2016)

\section{Pertumbuhan Perusahaan}

Pertumbuhan perusahaan didefinisikan mengindikasikan kemampuan perusahaan dalam mempertahankan kelangsungan usahanya. Pertumbuhan perusahaan dapat diproksikan dengan rasio pertumbuhan penjualan. Rasio ini mengukur seberapa baik perusahaan mempertahankan posisi ekonominya, baik dalam industrinya maupun dalam kegiatan ekonomi secara keseluruhan (Ariska et al., 2019)Pertumbuhan perusahaan merupakan kemampuan perusahaan dalam mempertahankan kelangsungan usahanya. (Saputra \& Kustina, 2018) Perusahaan yang mempunyai pertumbuhan laba yang tinggi, cenderung memiliki laporan yang sewajarnya, sehingga potensi untuk mendapatkan opini yang baik akan lebih besar. Pertumbuhan perusahaan ditunjukkan dari seberapa baik perusahaan mempertahankan posisi ekonomi dalam industri maupun kegiatan ekonomi secara keseluruhan (Nathan \& Scobell, 2012) Salah satu cara untuk mengetahui pertumbuhan perusahaan yaitu dengan melihat laba bersih yang dihasilkan perusahaan. Sementara perusahaan dengan rasio pertumbuhan penjualan negatif berpotensi besar mengalami penurunan laba sehingga manajemen perlu untuk mengambil tindakan perbaikan agar tetap dapat mempertahankan kelangsungan hidupnya. Laba bersih adalah prestasi manajemen yang telah menggunakan berbagai aset untuk mendapatkan laba bersih. (Setyarno, Januarti, \& Faisal, 2006)

\section{Profitabilitas}

Profitabilitas merupakan alat ukur kemampuan perusahaan dalam menghasilkan profit pada tingkat baik penjualan, aset dan modal sendiri. Perusahaan yang profitabilitasnya tinggi mengindikasikan perusahaan sanggup menjalankan usahanya dengan baik, dengan hal itu perusahaan bisa menjaga kelangsungan hidup (Izzati, 2014). Menurut Harahap (2009) rasio profitabilitas 


\section{Jurnal Riset Akuntansi dan Bisnis \\ Vol 21 No 1 2021, hal 15-25 \\ ISSN 1693-7597 (Print), 2623-2650 (online) \\ Available online: http://jurnal.umsu.ac.id/index.php/akuntan}

menggambarkan kemampuan perusahaan mendapatkan laba melalui semua kemampuannya, dan sumber yang ada seperti kegiatan penjualan, kas, ekuitas, jumlah karyawan, jumlah cabang dan sebagainya. Menurut Irham Fahmi (2012) semakin baik rasio Profitabilitas, maka semakin baik menggambarkan kemampuan tingginya perolehan keuntungan pada perusahaan. Berdasarkan teori diatas, maka dapat disimpulkan bahwa rasio Profitabilitas merupakan rasio untuk mengukur seberapa besar sebuah perusahaan mampu menghasilkan laba dengan menggunakan semua faktor perusahaan yang ada di dalamnya untuk menghasilkan laba yang maksimal.

\section{Solvabilitas}

Solvabilitas adalah kemampuan suatu perusahaan untuk memenuhi segala kewajiban finansialnya pada saat perusahaan tersebut dilikuidasi. Solvabilitas perusahaan dapat diukur dengan cara membandingkan jumlah aktiva (total aset) dengan jumlah utang (baik jangka pendek maupun jangka panjang). Solvabilitas merupakan kemampuan suatu perusahaan untuk membayar semua hutang-hutangnya baik jangka pendek maupun jangka panjang (Ramdhani, 2019).

Adapun jenis-jenis rasio yang ada dalam rasio Solvabilitas menurut Kasmir (2016) antara lain:
a) Debt To Total Asset Ratio (Debt Ratio) Debt To Asset Ratio (Debt Ratio)
b) Debt To Equity Ratio
Debt To Equity Ratio
c) Long Term Debt To Equity Ratio
d) Times Interest Earned
e) Fixed Charge Coverage

\section{Opini Audit Going Concern Tahun Sebelumnya}

Opini audit tahun sebelumnya adalah opini audit yang diterima auditee pada tahun sebelumnya atau 1 tahun sebelum tahun penelitian. Opini audit tahun sebelumnya ini dikelompokkan menjadi 2 yaitu auditee dengan opini going concern (GCAO) dan tanpa opini going concern (NGCAO). Apabila auditor memberikan opini audit going concen pada tahun sebelumnya, maka kemungkinan perusahaan akan menerima opini audit going concern kembali pada tahun berjalan akan semakin lebih besar Arni (2019).

\section{METODE PENELITIAN Jenis Penelitian}

Jenis penelitian yang digunakan dalam penelitian ini yaitu penelitian kuantitatif. Penelitian kuantitatif adalah data yang diukur dalam suatu skala numerik (angka) yang dapat dianalisis dengan menggunakan analisis statistik. Penelitian kuantitatif, menekankan pada pengujian teori-teori melalui pengukuran variabel-variabel penelitian dengan angka dan melakukan analisis data dengan prosedur statistik (Indriantoro dan Supomo, 2014).

\section{Lokasi Penelitian}

Penelitian ini dilakukan pada semua perusahaan pertambangan yang terdaftar pada Bursa Efek Indonesia. Data diperoleh berdasarkan sumber www.idx.co.id yang terdaftar di Bursa Efek Indonesia, dimulai pada Januari 2020 sampai dengan Mei 2020.

\section{Populasi dan Sampel}

Populasi dalam penelitian ini adalah semua perusahaan pertambangan yang terdaftar di Bursa Efek Indonesia dengan jumlah populasi sebesar 41 perusahaan sumber edu saham.com. Berdasarkan kriteria pemilihan sampel yaitu perusahaan pertambangan yang terdaftar secara konsisten di Bursa Efek Indonesia selama periode 2014-2018 dan perusahaan pertambangan yang melaporkan laporan keuangan tahunan secara berturut-turut, yang terdaftar di Bursa Efek Indonesia pada periode 20142018, maka diperoleh sampel sebanyak 21 perusahaan. 
Jurnal Riset Akuntansi dan Bisnis

Vol 21 No 1 2021, hal 15-25

ISSN 1693-7597 (Print), 2623-2650 (online)

Available online: http://jurnal.umsu.ac.id/index.php/akuntan

HASIL PENELITIAN

\section{Tabel 6}

Hasil Analisis Regresi Logistik Berganda

\begin{tabular}{|l|c|c|c|c|}
\hline \multicolumn{1}{|c|}{ Variabel } & B & Wald & Sig & Ket \\
\hline Pertumbuhan Perusahaan (PP) &, 333 &, 785 &, 376 & H1 (Ditolak) \\
\hline Profitabilitas (ROA) & $-12,809$ & 7,800 &, 005 & H2 (Diterima) \\
\hline Solvabilitas (DER) &, 155 &, 674 &, 412 & H3 (Ditolak) \\
\hline Opini Audit (OA) & 3,080 & 25,619 &, 000 & H4 (Diterima) \\
\hline Constant & $-2,009$ & 17,919 &, 000 & \\
\hline
\end{tabular}

Berdasarkan hasil uji regresi logistik diatas, maka dapat disimpulkan persamaan regresi sebagai berikut :

$$
\operatorname{Ln} \frac{O G C}{1-O G C}=-2,009+0,333 \mathrm{PP}-12,809 \mathrm{ROA}+0,155 \mathrm{DER}+, 080 \mathrm{OA}+\mathrm{e}
$$

Berdasarkan persamaan dari pengujian regresi logistik diatas maka hasil tersebut dapat di interpretasikan sebagai berikut :

1. Nilai konstanta sebesar $-2,009$, hal ini menujukkan bahwa nilai opini audit going concern sebesar $-2,009$ jika tidak ada variabel independent (pertumbuhan perusahaan (PP), profitabitas (ROA), solvabilitas (DER) dan opini audit going concern tahun sebelumnya).

2. Koefisien regresi pertumbuhan perusahaan sebesar 0,333 , hal ini menunjukkan jika terdapat kenaikan $1 \%$ pada pertumbuhan perusahaan maka kemungkinan perusahaan akan menerima opini audit going concern meningkat sebesar 33,3\%.

3. Koefisien regresi Profitabilitas (ROA) sebesar $-12,809$, hal ini menunjukkan jika terdapat kenaikan pada profitabilitas (ROA) sebesar 1\% maka kemungkinan perusahaan akan menerima opini audit going concern menurun sebesar $128,09 \%$

4. Koefisien regresi Solvabilitas (DER) sebesar 0,155, hal ini menunjukkan jika terjadi kenaikan pada solvabilitas (DER) sebesar 1\% maka kemungkinan perusahaan akan menerima opini audit going concern meningkat sebesar $15,5 \%$.

5. Koefisien regresi opini audit sebelumnya sebesar 3,080, hal ini menunjukkan jika perusahaan memperoleh opini audit going concern sebelumnya (kode 1), maka kemungkinan perusahaan mendapatkan opini audit going concern meningkat sebesar $308 \%$.

\section{PEMBAHASAN}

\section{Pengaruh Pertumbuhan Perusahaan Terhadap Opini Audit Going Concern}

Variabel pertumbuhan perusahaan menunjukkan koefisien regresi sebesar 0,333 dengan tingkat signifikan pertumbuhan lebih besar dari $0,05(0,376>0,05)$. Maka dapat disimpulkan hipotesis ke-1 (H1) ditolak. Hal ini menunjukkan bahwa pertumbuhan perusahaan tidak berpengaruh terhadap opini audit going concern. Pertumbuhan perusahaan merupakan kemampuan dalam mempertahnakan kelangsungan usahanya. Ketika pertumbuhan perusahaan meningkat masih ada beban lain yang harus ditutupi sehingga laba perusahaan tidak mengikuti pertumbuhan perusahaan, seperti beban operasional ataupun utang perusahaan yang masih belum mampu untuk dibayar oleh perusahaan. Sehingga laba perusahaan menjadi kecil dan memungkinkan terjadinya peningkatan perusahaan menerima opini audit going concern. Jika pertumbuhan penjualan perusahaan tinggi tidak akan menjamin auditor memberikan opini audit going concern dikarenakan ketika pertumbuhan penjualan perusahaan tinggi maka akan memberikan pengaruh pada biaya produksi yang akan naik juga. Ketika perusahaan mengalami peningkatan laba maka akan menambah pendapatan auditee yang juga akan memberikan dampak pada biaya operasional yang dikeluarkan perusahaan (Saifudin, 2016). Hasil penelitian ini sejalan dengan hasil penelitian yang dilakukan oleh Putri, (2018) yang mengungkapkan pertumbuhan perusahaan tidak berpengaruh terhadap opini audit going concern, Saifuddin, (2016) mengungkapkan dalam penelitiannya pertumbuhan perusahaan tidak berpengaruh terhadap opini audit going concern. Pertumbuhan penjualan yang tinggi tidak menjamin auditee 


\section{Jurnal Riset Akuntansi dan Bisnis \\ Vol 21 No 1 2021, hal 15-25 \\ ISSN 1693-7597 (Print), 2623-2650 (online) \\ Available online: http://jurnal.umsu.ac.id/index.php/akuntan}

untuk tidak menerima opini audit going concern. Verdian, (2018) yang menunjukkan pertumbuhan perusahaan tidak berpengaruh signifikan terhadap opini audit going concern. Hasil Adrianto, (2018) mengungkapkan bahwa pertumbuhan perusahaan tidak berpengaruh terhadap opinin audit going concern. Hasil penelitian ini bertolak belakang dengan hasil penelitian yang dilakukan oleh Munir, (2015) yang menyatakan dalam penelitiannya bahwa Pertumbuhan perusahaan berpengaruh terhadap opini audit going concern karena pertumbuhan penjualan yang diatas rata-rata bagi suatu perusahaan pada umumnya didasarkan pada pertumbuhan yang cepat yang diharapkan dari industri dimana perusahaan itu beroperasi. Perusahaan dapat mencapai tingkat pertumbuhan diatas rata-rata dengan jalan meningkatkan pangsa pasar dari permintaan industri keseluruhan maka audit akan memberikan opini audit going concern.Hal ini membuktikan bahwa pertumbuhan perusahaan yang diproksikan menggunakan penjualan tidak bisa menjamin perusahaan mendapatkan atau menerima opini audit going concern. Karena peningkatan dalam penjualan tidak menjadi jaminan laba juga meningkat dikarenakan tidak diikuti kemampuan perusahaan memperoleh laba yang baik juga. Hal ini juga disebabkan karena adanya faktor lain sehingga laba tidak meningkat seiring meningkatnya penjualan perusahaan, sehingga laba yang dihasilkan perusahaan akan tetap turun.

\section{Pengaruh Profitabilitas Terhadap Opini Audit Going Concern}

Variabel profitabilitas yang diuji menggunakan hipotesis regresi logistik menghasilkan koefisien sebesar-12,809 dengan tingkat signifikan 0,005. Tingkat signifikan profitabilitas lebih kecil dari $0,005(0,005<0,05)$. Maka dapat disimpulkan Hipotesis ke-2 diterima. Profitabilitas merupakan alat ukur yang digunakan untuk mengetahui kemampuan perusahaan dalam menghasilkan laba yang berkaitan dengan penjualan, aktiva, dan saham pribadi profitabilitas dianggap alat yang valid atas pengukuran pelaksanaan operasi perusahaan, karena profitabilitas menjadi suatu alat pembanding berbagai alternatif investasi yang sesuai dengan tingkat risiko. Hasil penelitian ini sejalan dengan hasil penelitian yang dilakukan oleh Ira Kristiana (2012), Maryani Yunike Susanti Lako (2019), Hilda Amelia Harahap (2019) mengungkapkan bahwa profitabilitas berpengaruh negative terhadap opini audit going concern. Hasil penelitian ini bertolak belakang dengan hasil penelitian yang dilakukan oleh Delaura Arni (2019) yang menyatakan bahwa profitabilitas tidak berpengaruh terhadap opini audit going concern. Hal ini membuktikan bahwa variabel profitabilitas yang diproksikan ROA berpengaruh negative terhadap opini audit going concern. Hal ini disebabkan karena manajemen perusahaan mampu mengelola asset-aset perusahaan yang ada dengan baik sehingga menghasilkan laba yang efektif. Karena manajemen mampu mengelola asset dengan baik maka meningkatkan profitabilitas perusahaan sehingga manajemen mampu menjalankan usahanya dan perusahaan berhasil mempertahankan kelangsungan hidup perusahaannya.

\section{Pengaruh Solvabilitas Terhadap Opini Audit Going Concern}

Variabel solvabilitas menunjukkan tingkat signifikan lebih besar dari $0,05(0,412>0,05)$. Hal ini berarti Hipotesis ke-3 ditolak, maka dapat disimpulkan bahwa solvabilitas tidak berpengaruh terhadap opini audit going concern. Solvabilitas merupakan kemampuan suatu perusahaan dalam rangka membayar semua hutang-hutangnya baik hutang jangka pendek maupun hutang jangka Panjang. Hasil penelitian ini sejalan dengan teori hasil penelitian yang dilakukan oleh Lastanti (2016), yang mengungkapkan solvabilitas tidak berepengaruh terhadap opini audit going concern karena auditor akan melihat faktor lain dalam pemberian opininya seperti tingkat kebangkrutan dan kerugian yang berulang. Febriana (2016), mengungkapkan solvabilitas tidak berpengaruh terhadap opini audit going concern hal ini dikarenakan, auditor harus mempertimbangkan hal lainnya dalam memberikan opini audit going concern, misalnya kondisi ekonomi pada saat itu dan pertumbuhan penjualan setiap tahun. Arni (2019) mengungkapkan bahwa Solvabilitas yang diproksikan menggunakan DER tidak berpengaruh terhadap opini audit going concern namun bertentangan dengan hasil penelitian yang dilakukan oleh Bonita Riestianiko putri (2018) yang menyatakan bahwa solvabilitas berpengaruh terhadap opini audit going concern. Namun hasil ini bertolak belakang dengan hasil penelitian yang dilakukan oleh Lie (2016) dan Saifudin (2016) mengungkapkan bahwa solvabilitas berpengaruh terhadap opini audit going concern. Maka dapat disimpulan bahwa solvabilitas (DER) tidak berpengaruh terhadap opini audit going concern, hal ini terjadi karena adanya keraguan auditor dalam memberikan opini audit going concern. Keraguan tersebut didasarkan karena auditor tidak hanya mempertimbangkan rasio solvabilitas perusahaan namum mempertimbangkan hal lain juga yang menjadi dasar dalam pemberian opini audit going concern 


\section{Jurnal Riset Akuntansi dan Bisnis}

Vol 21 No 1 2021, hal 15-25

ISSN 1693-7597 (Print), 2623-2650 (online)

Available online: http://jurnal.umsu.ac.id/index.php/akuntan

seperti kondisi ekonomi pada tahun itu, tingkat penjualan setaip tahun dan tingkat kebangkrutan pada perusahaan itu.

\section{Pengaruh Opini Audit Going Concern Tahun Sebelumnya Terhadap Opini Audit Going Concern}

Variabel opini audit sebelumnya pada penelitian ini setelah diuji menggunakan uji regresi logistik menghasilkan koefisien regresi sebesar 3,080 dengan tingkat signifikan sebesar 0,000. Tingkat signifikan variabel opini audit sebelumnya lebih kecil dari $0,05(0,000<0,05)$. Opini audit going concern tahun sebelumnya adalah opini audit yang diterima auditee pada tahun sebelumnya atau 1 tahun sebelum tahun penelitian. Hasil penelitian ini sejalan dengan teori dari hasil penelitian yang dilakukan oleh Wulansari, (2017) mengungkapkan opini audit going concern tahun sebelumnya berpengaruh terhadap opini audit going conern hal ini terjadi dikarenakan semakin tinggi perusahaan menerima opini audit going concern pada tahun sebelumnya semakin tinggi potensi menerima opini audit going concern pada tahun berjalan dan Muhammad Fahmi, (2015) mengungkapkan opini audit sebelumnya berpengaruh terhadap opini audit going concern hal ini dikarenakan opini audit going concern tahun sebelumnya menjadi faktor utama dalam pemberian opini audit pada tahun berjalan. Wahasusmiah (2018), Febriana (2016), Arni (2019) dan Misbakhul Munir (2015) mengungkapkan bahwa opini audit going concern tahun sebelumnya berpengaruh terhadap opini audit going concern

Hal ini terjadi karena dalam memberi opini auditor akan mempertimbangkan keputusannya dengan melihat opini audit sebelumnya. Karena Auditor akan membandingkan data pada tahun kerja dengan tahun sebelumnya. Perusahaan yang menerima opini audit going concern tahun sebelumnya cenderung akan berdampak pada harga kemunduran harga saham, kesulitan dalam meningkatkan modal pinjaman, ketidak percayaan investor, kreditur, pelanggan dan karyawan. Auditor juga akan melihat apakah ada perubahan pada kondisi keuangan perusahaan dari tahun sebelumnya atau menunjukkan peningkatan dari tahun sebelumnya sehingga auditor akan memberikan opini audit going concern, sehingga semakin besar kemungkinan auditor untuk mengeluarkan opini audit going concern pada tahun berjalan (Fahmi, 2015). Jika ditemukannya bukti bahwa perusahaan menerima opini audit going concern pada tahun sebelumnya maka perusahaan cenderung akan menerima opini yang sama dengan tahun sebelumnya yang akan digunakan pada tahun berjalan.

\section{Pengaruh Pertumbuhan Perusahaan, Profitabilitas, Solvabilitas dan Opini Audit Going Concern Tahun Sebelumnya terhadap Opini Audit Going Concern}

Hasil penelitian menunjukkan nilai signifikansi sebesar 0,000. Berdasarkan hasil tersebut, karena nilai signifikansi lebih kecil dari 0,05 maka model dapat disimpulkan mampu memprediksi nilai observasinya atau dapat dikatakan model fit. Model lebih baik dalam mencocokkan dibandingkan dengan model sederhana. Variabel pertumbuhan perusahan, profitabilitas, solvabilitas dan opini audit going concern tahun sebelumnya berpengaruh secara simultan terhadap opini audit going concern. Dilihat dari tabel koefisien determinasi bahwa variabel pertumbuhan perusahaan, profitabilitas (ROA), solvabilitas (DER) dan opini audit going concern tahun sebelumnya menunjukkan nilai nagelkerke $R$ Square sebesar $62,3 \%$, hal ini berarti bahwa seluruh variabel independent berpengaruh sebesar 62,3\% terhadap variabel dependent dan 37,7\% nya dipengaruhi oleh variabel lain, seperti likuiditas yang diteliti oleh Maryani Yunike Susanti Lako (2019) dan Bonita Riestianiko Putri (2018), Debt Default yang diteliti oleh Poppy Indriani dan Rolia Wahasusmiah (2018), dan Solvabilitas yang diproksikan menggunakan DAR (Arif Saifudin, 2016).

Perusahaan yang mengalami naik turunnya pertumbuhan penjualan, tinggi rendahnya tingkat profitabilitas, tinggi rendahnya tingkat solvabilitas dan adanya opini audit going concern tahun sebelumnya secara bersama-sama dapat mempengaruhi perusahaan menerima opini audit going concern. Dari hasil penelitian menunjukkan bahwa variabel bebas (pertumbuhan perusahaan, profitabilitas, solvabilitas dan opini audit going concern tahun sebelumnya) berpengaruh secara bersama-sama terhadap variabel terikat (opini audit going concern). Perusahaan yang mengalami naik turunnya pertumbuhan penjualan perusahaan, tinggi rendahnya tingkat profitabilitas, mampu dan tidak mampunya perusahaan dalam membayar hutangnya dan adanya opini audit going concern tahun sebelumnya dapat menyebabkan perusahaan menerima opini audit going concern dari auditor. Hal ini terjadi keempat variabel mampu memberikan faktor yang lebih besar secara bersama -sama sehingga membuat pihak auditor untuk memberikan opini audit going concern terhadap perusahaan. Hal ini terjadi dikarenakan ketika perusahaan menerima opini audit going concern tahun sebelumnya 


\section{Jurnal Riset Akuntansi dan Bisnis}

Vol 21 No 1 2021, hal 15-25

ISSN 1693-7597 (Print), 2623-2650 (online)

Available online: http://jurnal.umsu.ac.id/index.php/akuntan

perusahaan cenderung akan memperbaiki tingkat pertumbuhan penjualan menajdi lebih baik, ketika perusahaan sudah memiliki pertumbuhan penjualan yang tinggi maka perusahaan memiliki manajemen yang baik sehingga dapat mengelola asset perusahaan yang dapat meningkatkan tingkat profitbailits menjadi lebih baik, ketika perusahaan memiliki tingkat profitabilitas yang baik. Namun disisi lain perusahaan belum dapat dikatakan mampu untuk menutupi atau membayar hutang perusahaan yang ada hal ini disebabkan lebih tingginya hutang yang ada dari pendapatan perusahaan maka perusahaan dalam hal ini akan menerima opini audit going concern dari pihak auditor. Ketika perusahaan yang menerima opini audit going concern tahun sebelumnya dapat dikatakan perusahaan memiliki masalah keuangan dalam perusahaannya sehingga perusahaan tersebut akan menerima opini audit going concern pada tahun berjalan. Seluruh variabel bebas pertumbuhan perusahaan, profitabilitas, solvabilitas dan opini audit going concern tahun sebelumnya secara bersama-sama dapat mempengaruhi opini audit going concern. Hal ini mungkin dapat terjadi karena banyaknya sampel perusahaan pertambangan dari tahun 2014-2018 yang diteliti pada penelitian ini menerima opini audit going concern. Sampel perusahaan yang menerima opini audit going concern sebanyak 13 perusahaan dan 8 perusahaan tidak menerima opini audit going concern. Namun hasil penelitian ini sejalan dengan hasil penelitian dari Delaura Arni (2019) yang menyatakan bahwa Rasio Profitabilitas, pertumbuhan perusahaan dan opini audit going concern tahun sebelumnya secara simultan berpengaruh terhadap opini audit going concern.

\section{KESIMPULAN \\ Kesimpulan}

Setelah menganalisis data dan mendapatkan hasil penelitian serta diuraikan dalam pembahasan ini adalah sebagai berikut :

1. Tingkat signfikan pertumbuhan perusahaan $0,376>0,05$. Pertumbuhan perusahaan tidak berpengaruh terhadap opini audit going concern. Hal ini disebabkan pertumbuhan perusahaan yang mengalami kenaikan ataupun penurunan tidak menjadi pertimbangan auditor untuk mengeluarkan opini audit going concern.

2. Tingkat signifikan profitabilitas $0,005<0,05$. Profitabilitas berpengaruh terhadap opini audit going concern. Hal ini disebabkan ketika perusahaan mengalami profitabilitas yang tinggi, maka perusahaan dikatakan mampu mempertahankan kelangsungan usahanya. Sehingga menurunkan kemungkinan pemberian opini audit going concern oleh auditor.

3. Tingkat signifikan solvabilitas $0,412>0,05$. Solvabilitas tidak berpengaruh terhadap opini audit going concern. Hal ini disebabkan karena adanya keraguan auditor dalam memberikan opini audit going concer dan adanya pertimbangan lain dalam memberikan opini audit going concern selain solvabilitas, seperti kemampuan perusahaan melunasi utang dan memperbaiki operasional dan melaporkan keuangan dengan wajar.

4. Tingkat signifikan opini audit going concern tahun sebelumnya $0,000<0,05$. Opini audit going concern tahun sebelumnya berpengaruh terhadap opini audit going concern. Hal ini menunjukkan bahwa dalam penerbitan opini audit going concern maka auditor akan mempertimbangkan opini audit going concern yang telah diterima perusahaan pada tahun sebelumnya dan menggunakannya pada tahun berjalan.

5. Nilai signifikansi pada uji omnibus sebesar $0,000<0,05$ maka variabel pertumbuhan perusahan, profitabilitas, solvabilitas dan opini audit sebelumnya berpengaruh secara simultan terhadap opini audit going concern. Hal ini mungkin disebabkan dari 21 sampel perusahaan dari tahun 2014 sampai dengan 2018 ada 13 perusahaan atau 61,9\% yang menerima opini audit going concern sedangkan sampel perusahaan dari tahun 2014-2018 yang tidak menerima opini audit going concern hanya sebanyak 8 perusahaan atau sebesar $38,1 \%$.

\section{DAFTAR PUSTAKA}

Alpi, M. F. (2018). Pengaruh Debt to Equity Ratio, Inventory Turn Over, dan Current Ratio terhadap Return on Equity pada Perusahaan Sektor Farmasi yang Terdaftar di Bursa Efek Indonesia. The National Conference on Management and Business (NCMAB).

Alpi, M. F., \& Gunawan, A. (2018). Pengaruh Current Ratio Dan Total Assets Turn Over Terhadap Return On Assets Pada Perusahaan Plastik dan Kemasan. Jurnal Riset Akuntansi : Aksioma, 17(2), 1-36. 


\section{Jurnal Riset Akuntansi dan Bisnis}

Vol 21 No 1 2021, hal 15-25

ISSN 1693-7597 (Print), 2623-2650 (online)

Available online: http://jurnal.umsu.ac.id/index.php/akuntan

Adrianto, F. (2018). Pengaruh Ukuran Kap, Opini Audit Tahun Sebelumnya, Pertumbuhan Perusahaan, Solvabilitas \& Profitabilitas, Terhadap Opini Audit Going Concerndengan Kondisi Keuangan Sebagai Variabel Moderating (Studi Empiris Pada Perusahaan Manufaktur Sub Sektor Industri D.

Ariska, E. Y., Maslichah, \& Afifudin. (2019). Pengaruh Audit Tenure, Opinion Shoppping, Leverage Dan Pertumbuhan Perusahaan Terhadap Penerimaaan Opini Audit Going Concern Pada Perusahaan Manufaktur Yang Terdaftar Di Bursa Efek Indonesia 2015-2017. E-Jurnal Riset Akuntansi, 8(6), 157-170.

Arni, D. (2019a). Pengaruh Opinion Shopping, Disclosure, Reputasi Kap Dan Opini Audit Tahun Sebelumnya Terhadap Opini Audit Going Concern (Studi Empiris Pada Perusahaan Properti, Real Estate, Dan Konstruksi Yang Terdaftar Di Bursa Efek Indonesia Periode 2012-2016). Artikel Ilmiah.

Arni, D. (2019b). Pengaruh Rasio Profitabilitas, Rasio Likuiditas, Rasio Solvabilitas, Pertumbuhan Perusahaan Dan Opini Audit Tahun Sebelumnya Terhadap Pemberian Opini Audit Going Concern Kasus Pada Perusahaan Sektor Pertambangan Yang Terdaftar Di Bei Tahun 20142018) Skri. 1789.

Fahmi, M. (2015). Pengaruh Audit Tenure, Opini Audit Tahun Sebelumnya, Dan Disclosure Terhadap Opini Audit Going Concern Perusahaan Tambang Dan Agriculture Yang Terdaftar Di Bei Tahun 2011-2014. Akuntabilitas, 8(3). Https://Doi.Org/10.15408/Akt.V8i3.2770

Febriana, S. Dan D. (2016). Analisis Pengaruh Rasio Likuiditas, Rofitabilitas, Solvabilitas, Aktifitas Dan Opini Audit Going Concern Tahun Sebelumnya Terhadap Opini Audit Going Concern (Studi Empiris Pada Perusahaan Real Estate \& Property Yang Terdaftar Di Bursa Efek Indonesia 2010-. Bisnis: Jurnal Bisnis Dan Manajemen Islam, 4(1), 58. Https://Doi.Org/10.21043/Bisnis.V4i1.1684

Ghozali, I. (2016). Aplikasi Analisis Multivariate Dengan Program Ibm Spss 23 (8th Ed.).

Hanafi, M. Dan A. . (2016). Analisis Laporan Keuangan (5th Ed.).

Harahap, S. (2009). Analisis Kritis Atas Laporan Keuangan.

Haris, R. Dan M. (2015). Pengaruh Debt Default, Disclosure, Opini Audit Tahun Sebelumnya, Ukuran Perusahaan, Dan Opinion Shopping Terhadap Penerimaan Opini Audit Going Concern. . . Journal Of Accounting, 4, 1-11.

Hidayat, A. (2018). Analisis Faktor-Faktor Keuangan Yang Berpengaruh Pada Penerimaan Opini Audit Going Concern. (Studi Empiris Pada Perusahaan Manufaktur Yang Terdaftar Di Bursa Efek Indonesia). 2, 1-11.

Izzati, S Dan L. . (2014). Fator- Fator Yang Mempengaruhi Penerimaan Opini Audit Going Concern Pada Perusahaan Manufatur Yang Terdaftar Di Bursa Efe Indonesia.

Krissindiastuti, M, \& R. (2016). Faktor-Faktor Yang Mempengaruhi Opini Audit Going Concern. EJurnal Akuntansi.

Lastanti, G. Windy. (2016). Pengaruh Opini Audit Tahun Sebelumnya, Reputasi Auditor, Ukuran Perusahaan, Profitabilitas, Likuiditas, Dan Solvabilitasterhadap Pemberian Opini Audit Going Concern. Iosr Journal Of Economics And Finance, 3(1), 56. Https://Doi.Org/Https://Doi.Org/10.3929/Ethz-B-000238666

Lie, C. Dkk. (2016). Pengaruh Likuiditas, Solvabilitas, Profitabilitas, Dan Rencana Manajemen Terhadap Opini Audit Going Concern (Studi Empiris Perusahaan Manufaktur Di Bei).

Berkala Akuntansi Dan Keuangan Indonesia, 1(2), 84-105. Https://Doi.Org/10.20473/Baki.V1i2.2694

Munir, Misbakhul. (2015). Pengaruh Kualitas Audit, Kondisi Keuangan, Opini Audit Tahun Sebelumnya, Dan Pertumbuhan Perusahan Terhadap Pengungkapan Opini Audit Going Concern. Https://Doi.Org/10.1.02.01.0111

Nathan, A. J., \& Scobell, A. (2012b). How China Sees America. In Foreign Affairs (Vol. 91, Issue 5, Pp. 1689-1699). Https://Doi.Org/10.1017/Cbo9781107415324.004

Nurdiono, Junaidi, \& Hartadi, B. (2016). The Effect Of Term Relationship Between The Auditor And Clients On Auditor Independence. International Journal Of Applied Business And Economic Research, 14(13), 9131-9146.

Putri, B. R. (2018). The 1st Multi-Discipinary International Conference University Of Asahan2019. Jurnal Akuntansi. 


\section{Jurnal Riset Akuntansi dan Bisnis}

Vol 21 No 1 2021, hal 15-25

ISSN 1693-7597 (Print), 2623-2650 (online)

Available online: http://jurnal.umsu.ac.id/index.php/akuntan

Putri, B.R. (2018). The 1st Multi-Discipinary International Conference University Of Asahan2019. Jurnal Akuntansi.

Ramdhani, A. (2019). Analisis Rasio Likuiditas, Solvabilitas, Profitabilitas, Dan Aktivitas Untuk Menilai Kinerja Keuangan Koperasi Sejahtera Analysis Of Liquidity, Solvability, Profitability, And Activity Ratio To Assess The Financial Performance Of The Sejahtera Coope. 6(1), 1-10.

Saifuddin, A. (2016). Pengaruh Ukuran Perusahaan, Profitabilitas, Likuiditas, Solvabilitas, Dan Pertumbuhan Perusahaan Terhadap Opini Audit Going Concern ( Studi Empiris Pada Perusahaan Manufaktur Yang Terdaftar Di Bursa Efek Indonesia (Bei) Tahun 2014-2016. Publikasi Ilmiah.

Saifuddin, A. (2016). Pengaruh Ukuran Perusahaan, Profitabilitas, Likuiditas, Solvabilitas, Dan Pertumbuhan Perusahaan Terhadap Opini Audit Going Concern (Studi Empiris Pada Perusahaan Manufaktur Yang Terdaftar Di Bursa Efek Indonesia (Bei) Tahun 2014-2016. Publikasi Ilmiah.

Verdian, A. (2018). Pengaruh Manajemen Laba, Pertumbuhan Perusahaan, Prediksi Kebangkrutan Dan Debt Default Terhadap Pengungkapan Opini Audit Going Concern Studi Empiris Pada Perusahaan Sektor Infrastruktur, Transportasi Dan Utilitas Yang Terdaftar Di Bursa Efek Indonesia Pe.

Vernando, A., \& Yuniarto, A. S. (2018). Faktor-Faktor Yang Mempengaruhi Penerimaan Opini Audit Going Concern. Jurnal Reksa: Rekayasa Keuangan, Syariah Dan Audit, 3(2), 129. Https://Doi.Org/10.12928/J.Reksa.V3i2.31

Wahasusmiah, I. Dan R. (2018). Pengaruh Kondisi Keuangan, Rasio Keuangan, Debt Default, Kualitas Audit, Dan Opini Audit Tahun Sebelumnya Terhadap Opini Audit Going Concern. Kajian Akuntansi, 19(1), 19-28.

Wulansari, K. (2017). Pengaruh Opinion Shopping, Disclosure, Reputasi Kap Dan Opini Audit Tahun Sebelumnya Terhadap Opini Audit Going Concern (Studi Empiris Pada Perusahaan Properti, Real Estate, Dan Konstruksi Yang Terdaftar Di Bursa Efek Indonesia Periode 2012-2016).

www.idx.co.id

www.PwC.com, 2016

www.sahamok.com

www.tribunnews.com 